\title{
Development and Validation of UV Spectrophotometric Method for Determination of Bisoprolol Fumarate in Bulk and Pharmaceutical Dosage Forms
}

\author{
Shahinaz A. Mohammed ${ }^{1}$, Mohammed E. Adam ${ }^{2}$ and Shaza W. Shantier ${ }^{2, *}$ \\ ${ }^{1}$ Department of Pharmaceutical Chemistry, Faculty of Pharmacy, Omdurman Islamic University Omdurman, \\ Sudan \\ ${ }^{2}$ Department of Pharmaceutical Chemistry, Faculty of Pharmacy, University of Khartoum, P.O. Box 1996, \\ Sudan
}

\begin{abstract}
In this study a simple, accurate and precise UV- spectrophotometric method was developed for the estimation of bisoprolol fumarate $(\mathrm{BF})$ in bulk and tablet dosage form. The method was based on measurement of absorbance of BF aqueous solution at $271 \mathrm{~nm}$. Validation was conducted in accordance to ICH guidelines. The calibration curve was linear in the concentration range $5-25 \mu \mathrm{g} / \mathrm{mL}$ with correlation coefficient not less than 0.9986. The limit of detection and limit of quantification were $0.22 \mu \mathrm{g} / \mathrm{ml}$ and $0.66 \mu \mathrm{g} / \mathrm{ml}$, respectively. Intraday and intermediate precision of the developed method were reflected by the low RSD\% values (1.19 and 0.854 , respectively). The recovery percentage was $105.0 \pm 1.3 \%, n=3$. The proposed method was applied for the assay of $\mathrm{BF}$ in three different brands.
\end{abstract}

Keywords: Bisoprolol fumarate; UV spectrophotometric method; Brands.

\section{Introduction}

Bisoprolol fumarate (BF; Figure 1) is a selective betablocker. It is used for the treatment of hypertension, angina pectoris ${ }^{1,2}$. Several methods were reported for the determination of BF in bulk and dosage form as single component, combined with other drugs or in biological fluids. These methods include electrochemical ${ }^{3}$, UV spectrophotometric methods ${ }^{4-7}$ and HPLC methods ${ }^{8-12}$. The official method for its analysis is an HPLC method which considered time consuming and expensive specially in developing countries.

On the other hand, UV spectrophotometry is fast, simple, economic and universally accepted in pharmaceutical analysis. A literature survey revealed that no UV spectrophotometric method has been reported for the estimation of $\mathrm{BF}$ in pharmaceutical formulations individually.

Thus, the present study describes a direct, simple and accurate method for the estimation of BF in bulk and in tablet dosage forms.<smiles>CC(C)NCC(O)COc1ccc(COCCOC(C)C)cc1</smiles>

Fig. 1. The structural formula of bisoprolol fumarate 


\section{Experimental}

Materials:

Bisoprolol fumarate reference standard (100.5\%) was kindly provided by Azal Pharma, Sudan. Pharmaceutical products of the three commercial brands (Tablets; $5 \mathrm{mg}$ ) were purchased from the local market.

Instrumentation: UV-Vis spectrophotometer, Jenway 7315 single beam.

\section{Methodology: \\ Preparation of stock solutions}

\section{BF standard solution}

Accurately weighed amount $(5 \mathrm{mg})$ of BF standard was dissolved in about $70 \mathrm{ml}$ of distilled water. The solution was then transferred into $100 \mathrm{ml}$ volumetric flask and volume completed to mark with distilled water (solution A; $50 \mu \mathrm{g} / \mathrm{ml}$ ).

\section{BF sample solution}

Twenty tablets were weighed and powdered. An equivalent weight to $5 \mathrm{mg}$ was transferred to $100 \mathrm{ml}$ volumetric flask, dissolved in distilled water and shaken for 15 minutes. The volume was then completed to mark with distilled water. The solution was then filtered (solution B; $50 \mu \mathrm{g} / \mathrm{ml}$ ).

\section{Estimation of maximum wavelength}

Solution A was scanned between 240 to $400 \mathrm{~nm}$ to establish the maximum wavelength of absorption $\left(\lambda_{\max }\right)$.

\section{Construction of Calibration curve}

Aliquot volumes of solution A $(1-5 \mathrm{ml})$ were transferred into a set of volumetric flasks $(10 \mathrm{ml})$. The volumes were then completed to mark with distilled water to obtain concentration range of $5-25 \mu \mathrm{g} / \mathrm{ml}$. The absorbance values of these solutions were measured at $271 \mathrm{~nm}$ against blank (distilled water). Calibration curve was constructed by plotting absorbance values vs concentration.

\section{Method Validation}

The developed method was validated as per the ICH guidelines ${ }^{13}$ in terms of linearity, precision, accuracy and specificity.

\section{Linearity}

LOD, LOQ, slope error and intercept error were calculated from the concentration range, absorbance data and slope.

\section{Precision}

Different concentrations within the linearity range were prepared and analysed three times within the same day and between days to evaluate the precision of the developed method. The mean, standard deviation and relative standard deviation values were calculated.

\section{Accuracy}

Two ml each of solution B were transferred into three volumetric flasks. Study was carried out through spiking solutions at 50\%, $100 \%$ and $150 \%$ levels. The absorbance values were measured and the recovery percentage was calculated. The procedure was repeated three times.

\section{Assay of tablets dosage form}

The absorbance of sample and standard solutions with the same concentration was measured at $271 \mathrm{~nm}$. The procedure was repeated three times and the content percent was calculated as follows.

$(\%)=$ Absorption of the sample / Absorption of the standard $\times 100 \%$.

\section{Results and Discussion}

Although UV spectrophotometry lacks selectivity, it is the most widely used method for quantitative analysis of raw materials and pharmaceutical dosage forms. This is due to its simplicity and accuracy.

The developed method describes the analysis of BF using direct UV method. Aqueous solution of BF showed maximum absorption at $271 \mathrm{~nm}$ (Figure 2).

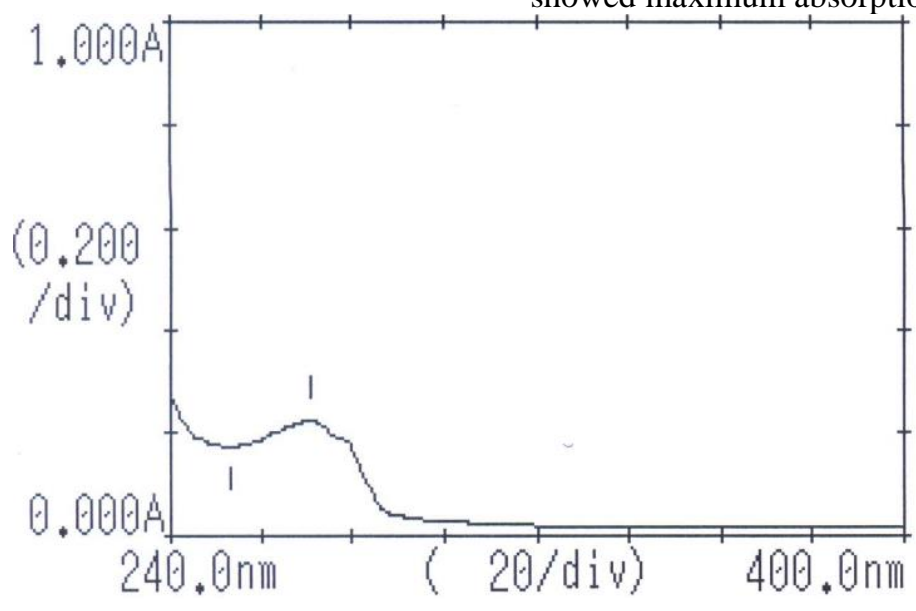

Figure 2. UV spectrum of BF aqueous solution (271nm; $5 \mu \mathrm{g} / \mathrm{ml})$ 


\section{Method validation}

\section{Linearity}

The linearity of the method was checked in pure solution of BF. Regression analysis of Beer's plots showed good correlation in concentration range of
5-25 $\mu \mathrm{g} / \mathrm{ml}$ with good correlation coefficient (Figure 3).

The obtained regression analysis data was summarized in Table 1.

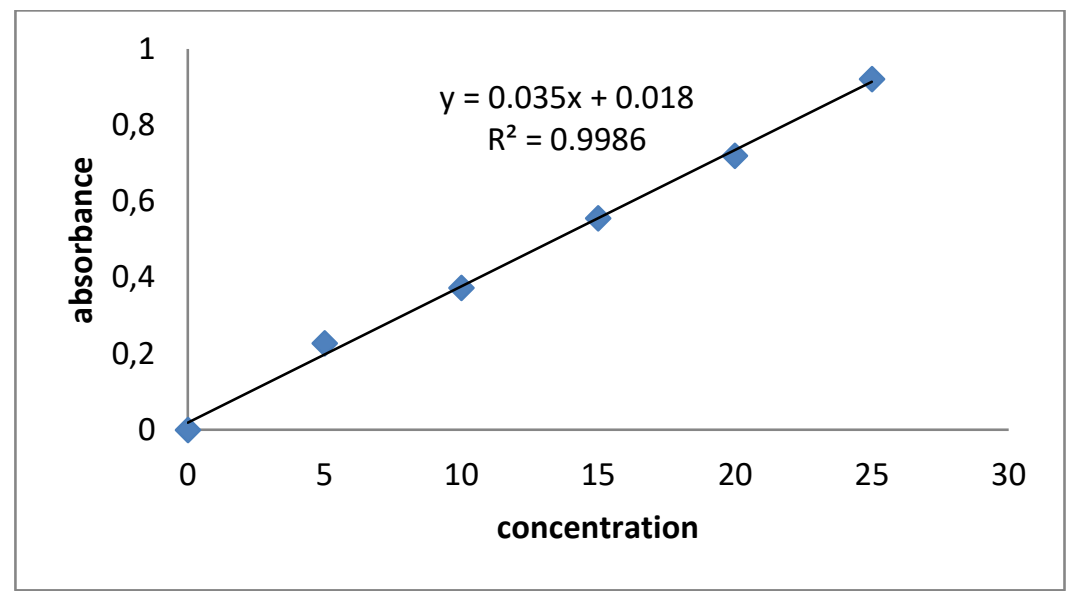

Figure 3. Calibration curve of BF

Table 1. Linearity data of the developed method.

\begin{tabular}{|l|l|}
\hline Parameter & Developed method \\
\hline Conc. range & $5-30 \mu \mathrm{g} / \mathrm{ml}$ \\
\hline Slope $\pm \mathrm{ts}_{\mathrm{b}}{ }^{*}$ & $0.035 \pm 0.48$ \\
\hline Intercept $\pm \mathrm{ts}_{\mathrm{a}^{* *}}$ & $0.018 \pm 0.056$ \\
\hline Correlation coefficient & 0.9986 \\
\hline LOD & $0.22 \mu \mathrm{g} / \mathrm{ml}$ \\
\hline LOQ & $0.66 \mu \mathrm{g} / \mathrm{ml}$ \\
\hline
\end{tabular}

*Standard error of slope calculated at $95 \%$ confidence limit for $\mathrm{n}-2$ degrees of freedom.

** Standard error of intercept calculated at $95 \%$ confidence limit for $\mathrm{n}-2$ degrees of freedom

\section{Precision}

The precision of the developed method was assessed in terms of repeatability and intermediate precision by analyzing replicate for three different concentrations. RSD\% values were 1.19 and 0.854 reflecting the precision of the developed method $(\% \mathrm{RSD}<2)$.

\section{Accuracy}

The accuracy of the method was determined by recovery experiments. The recovery studies were carried out at spiking levels of 50\%, 100\% and $150 \%$ of test concentration. Results of assay and recovery were presented in Table 2.

The obtained results reflect the accuracy of the method and its freedom of interferences by excipients.

Table 2. Accuracy of the developed method

\begin{tabular}{|c|c|c|c|}
\hline $\begin{array}{l}\text { Amount of sample } \\
(\mu \mathrm{g} / \mathrm{ml})\end{array}$ & $\begin{array}{l}\text { study level } \\
(\%)\end{array}$ & $\begin{array}{l}\text { Amount of drug } \\
\text { added }(\mu \mathrm{g} / \mathrm{ml})\end{array}$ & Recovery \% $\%$ SD; $\mathbf{n}=3$ \\
\hline - e & $\begin{array}{l}50 \\
100 \\
150\end{array}$ & $\begin{array}{l}10 \\
20 \\
30\end{array}$ & $\begin{array}{l}105.9 \pm 1.36 \\
107.4 \pm 1.90 \\
105.5 \pm 1.30\end{array}$ \\
\hline
\end{tabular}

\section{Assay of BF tablets dosage forms by developed method}

The developed method was applied for the assay of BF in three commercial brands collected from Sudan market.
The obtained results showed good content percent of $\mathrm{BF}$ in the three brands which complies with the stated percent (90-105\%), Table 3. 
Table 3. Assay of BF tablets dosage form by developed method

\begin{tabular}{|c|c|c|}
\hline Brand code & $\begin{array}{l}\text { Labeled amount } \\
\text { (mg/tablet) }\end{array}$ & Content $\% \pm \mathrm{SD} ; \mathrm{n}=\mathbf{3}$ \\
\hline $\begin{array}{l}\text { B1 } \\
\text { B2 } \\
\text { B3 }\end{array}$ & $\begin{array}{l}5 \\
5 \\
5\end{array}$ & $\begin{array}{l}105.1 \pm 0.17 \\
100 \pm 0.001 \\
90.48 \pm 0.35\end{array}$ \\
\hline
\end{tabular}

\section{Conclusion}

An accurate and precise UV spectrophotometric method has been developed and validated for the analysis of Bisoprolol fumarate in bulk and tablet dosage form. The percentage recovery and found concentration of active ingredient in pharmaceutical formulations showed that the amount of drug present is consistent with the label claim. Hence, this method is very useful simple and accurate for determination of Bisoprolol fumarate in bulk and pharmaceutical dosage form. It can be used for the routine analysis of BF.

\section{References}

1. T.F. Ligenli, F. Kilicaslan, A. Kirilmaz, M. Uzun, Bisoprolol improves echocardiographic parameters of left ventricular diastolic function in patients with systemic hypertension, Cardiology, 2006, 106, 127-131.

2. J.K. Mc Gavin, G.M. Keating, Bisoprolol: A review of its use in chronic heart failure, Drugs, 2002, 62, 267-269.

3. R.N. Goyal, A. Tyagi, N. Bachheti, S. Bishnoi, Voltammetric determination of bisoprolol fumarate in pharmaceutical formulations and urine using single-wall carbon nanotubes modified glassy carbon electrode, Electrochimica Acta, 2008, 53, 28022808

4. R. Sahu, V.B. Patel, Simultaneous spectrophotometric estimation of hydrochlorothiazide and bisoprolol fumarate in combined dosage forms, Indian Journal of Pharmaceutical Sciences, 2006, 68, 764 - 767

5. A.D. Panainte, N. Bibire, G. Tantaru, M. Apostu, M. Vieriu, and V. Dorneanu, A new method for the assay of bisoprolol using bromocresol green. Rev. Chim. (Bucharest), 2014, 65(8), 916-920.
6. A.D. Panainte, N. Bibire, G. Tantaru, M. Apostu, M. Vieriu, and V. Dorneanu, Spectrophotometric method for the estimation of bisprolol fumarate in tablets, Rev. Med. Chir. Soc. Med. Nat lasi., 2014, 118 (2), 558-563.

7. A.D. Gudruman, A. Murarasu, and V. Dorneanu, Spectrophotometric determination of bisoprolol using methyl orange as reagent. Farmacia, 2012, 60(5), 634-640

8. D.N. Vora, A.A. Kadav, Development and validation of a simultaneous HPLC method for estimation of bisoprolol fumarate and amlodipine besylate from tablets, Indian Journal of Pharmaceutical Sciences, 2008, 70, 542-546

9. S. Shaikh, O.A. Thusleem, M.S. Muneera, J. Akmal, A.V. Kondaguli, K. Ruckmani, A simple and rapid high-performance liquid chromatographic method for the determination of bisoprolol fumarate and hydrochlorothiazide in a tablet dosage form, Journal of Pharmaceutical and Biomedical Analysis, 2008, 48, 1055-1057.

10.E. Caudron, S. Laurent, E.M. Billaud, P. Prognon, Simultaneous determination of the acid/base antihypertensive drugs celiprolol, bisoprolol and irbesartan in human plasma by liquid chromatography, Journal of Chromatography B, 2004, 801, 339-345.

11. C. Oniscu, C.V. Vlase, G. Peste, A new highperformance liquid chromatographic method for determination of bisoprolol in plasma samples, Romanian Biotechnological Letters, 2007, 12, 3079-3084.

12. K. Konam, J. Soujanya, M. Sasikala, and A.K. Kumar, Development and validation of RP-HPLC method for the determination of bisoprolol fumarate tablets. International Journal of Research in Pharmaceutical and Nano Sciences, 2013, 2(1), 57-58.

13. ICH G. Validation of analytical procedures: text and methodology. Q2 (R1). 2005;1. 